\title{
RESEARCH OF KIROVSK RESERVOIR FOR DEVELOPING MOBILE ACTIVE HYDROACOUSTIC FISH PROTECTING DEVICE ${ }^{1}$
}

\author{
A. N. Tumenov, S. Zh. Assylbekova, A. I. Kim, A. A. Mukhramova \\ Fisheries Research and Production Center, LLP, \\ Almaty, Republic of Kazakhstan
}

\begin{abstract}
The hydrological, hydrobiological and ichthyological parameters of the Kirovsk Reservoir in the West Kazakhstan region of the Republic of Kazakhstan are described. The reservoir was selected as a model for realization of the grant project No. AP09058066 "Developing mobile active hydroacoustic fish protecting device to protect fish and juveniles from entering the dam spillways of large hydroelectric power plants and reservoirs" of the Ministry of Education and Science of the Republic of Kazakhstan. Hydrological, hydrobiological and ichthyological studies were aimed to obtain data for making optimal decisions on the design, equipment and working algorithm of the fish protection device. Hydrological studies include measuring depths and current speed in the water area of the reservoir and in front of the dam spillway. The species composition, abundance and biomass of forage invertebrates of zooplankton and zoobenthos were studied as hydrobiological indicators. The main biological indicators, fish abundance and biomass, species composition and concentration of juveniles were taken into account when studying ichthyological data. The obtained hydrological, hydrobiological and ichthyological parameters of the Kirov Reservoir served as the basis for developing the concept of a mobile active hydroacoustic fish protecting device to prevent fish and juveniles from entering the spillways of dams at the large hydroelectric power plants and reservoirs.
\end{abstract}

Key words: reservoir, dam, depth, current, zooplankton, zoobenthos, biomass, fish, concentration.

For citation: Tumenov A. N., Assylbekova S. Zh., Kim A. I., Mukhramova A. A. Research of Kirovsk Reservoir for developing mobile active hydroacoustic fish protecting device. Vestnik of Astrakhan State Technical University. Series: Fishing Industry. 2021;3:102-108. (In Russ.) DOI: 10.24143/2072-9502-2021-3-102-108.

\section{Introduction}

The Kirov Reservoir is the first in the cascade of the reservoirs of the Ural-Kushum irrigationwatering system [1]. According to the list of the fishery reservoirs of local importance [2], its area makes 3000 hectares. A water filling source is the Ural River. The reservoir has a retaining dam with a spillway. Stability of the water regime with periodic water discharges, presence of a capital regulated hydraulic structure and a variety of ichthyofauna create conditions for designing fishery devices suitable for this kind of reservoirs, which was chosen as a model reservoir.

At the first stage of research there have been conducted the hydrological, hydrobiological and icthyological studies of a reservoir covering such indicators as depth, speed of a current, specific structure, number and biomass of feed invertebrates, zooplankton and zoobenthos, specific features, basic biological indicators, fish number and biomass, specific structure and concentration of juveniles. The obtained data served as a basis for working out a concept of a fishery device.

The purpose of the given research was studying hydrological, hydrobiological and icthyological parameters of the reservoir for the purpose of data acquisition for making optimum decisions on a design, a complete set and a working algorithm of the projected fishery device.

\section{Materials and techniques}

Studying the hydrological indicators was carried out by using a technique of quantitative definition and the account of elements of the reservoirs [3]. The depth was measured by the Harmin EHO 150 echo sounder, and the speed of a current - by hydrometric revolving object GMCM 1. In total, 75 measurements of depths and 85 measurements of the current speed have been made.

\footnotetext{
${ }^{1}$ This research has been/was/is funded by the Science Committee of the Ministry of Education and Science of the Republic of Kazakhstan (Grant No. AP09058066 Development of the active mobile hydroacoustic fish-protecting device for protection of juveniles from hit in spillways of HPS dams, reservoirs).
} 
The data on the state of fish fodder resources were collected and processed, according to the standard techniques $[4,5]$. For the analysis of the state of the forage reserve there has been made sampling of zooplankton and macrozoobenthos for the purpose of defining the specific structure, number and biomass of the most important species of fodder organisms. In total, 10 tests of zooplankton and 15 tests of zoobenthos have been selected.

Scientific catches were made by the nets with mash size from 22 to $80 \mathrm{~mm}$. In total, there were made 10 scientific catches. Sampling fish juveniles was made by fry circle of Rass and by fry drag. The species definition of fish and juveniles resulted in the well-known benefits $[6,7]$. The ichthyological researches were carried out by using the standard methodical management [8]. In total, 320 fish species were defined, according to the specific, age and size-weighting composition of ichthyofauna.

The research of fish concentration was conducted by using the method of echoshooting [9]. To define the concentration, migrations and downstream of the fish juveniles there have been taken 20 tests with the early juveniles by using the circle of Rass and 10 tests of the late juveniles by the fry drag.

\section{Results Discussion}

Hydrological indicators. The Kirov Reservoir basin has an even profile of a bottom. The reservoir volume at the normal retaining level makes 60 million $\mathrm{m}^{3}$. During the dry summer season the depth of the channel ranges from 2.5 to $3.2 \mathrm{~m}$. During the spring flood the level increases due to the waters coming from the Ural River, and the depth grows up to 3.5-4.2 m. Before the dam spillway the depth increases a little, which is caused by a stronger current washing away the ground $(2.7-3.5 \mathrm{~m}$ in the offseason, and 3.7-4.5 $\mathrm{m}$ in the spring high water).

The speed of the current is also an important hydrological indicator. The speed of a current was measured from a motor boat (Fig.).

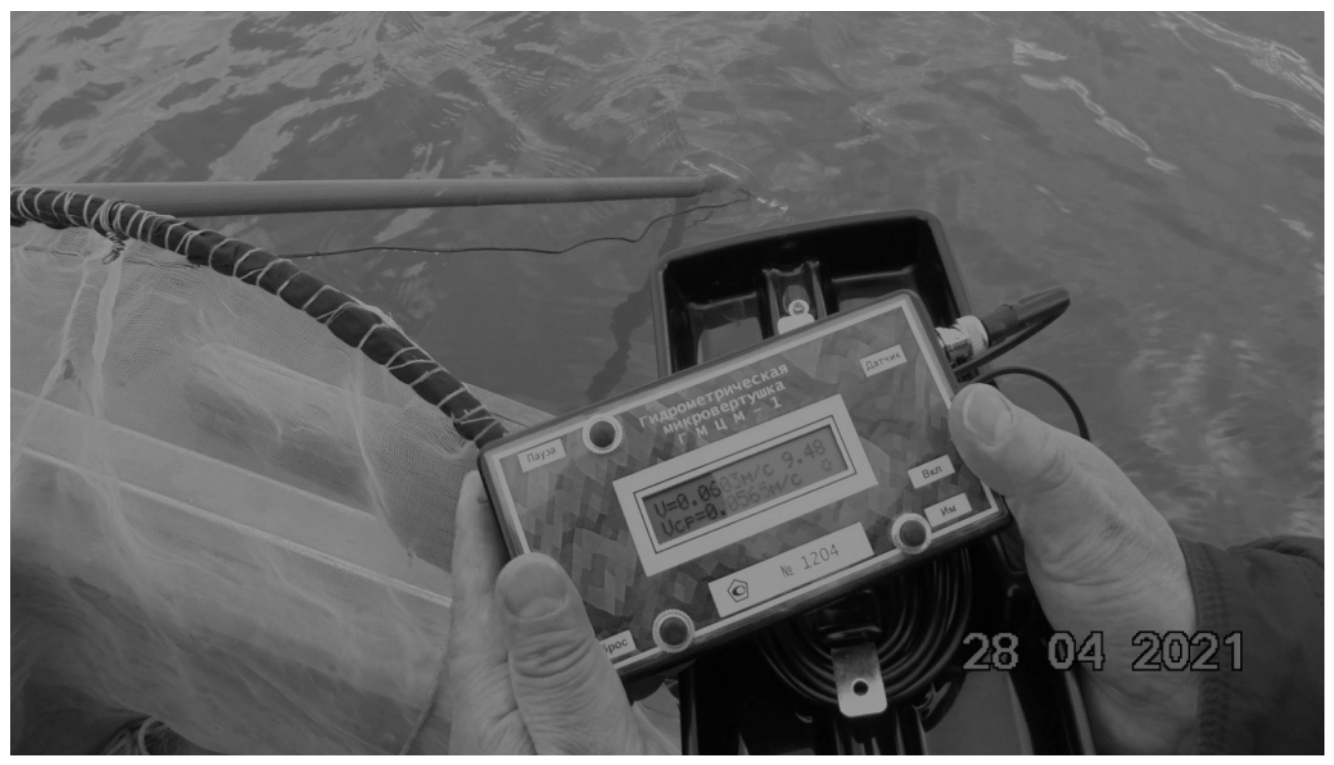

Measuring current speed

The current speed in the reservoir is observed only during the water admission through the dam spillway. In the spring time through the spillway the water is dumped with $35-40 \mathrm{~m}^{3} / \mathrm{s}$, during summer and autumn drought seasons the speed of the current is $25 \mathrm{~m}^{3} / \mathrm{s}$. During peak of the spring high water $\left(3^{\mathrm{d}}\right.$ decade of April), when the water passes through the dam waterworks, the water maximum quantity is dumped, the speed of a current on the water bringing channel increases to $1.94 \mathrm{~m} / \mathrm{s}$. It is caused by the fact that weight of water in the pre-dam parts getting to the narrow water bringing channel considerably accelerates. However, on removal in radius of $100 \mathrm{~m}$ from the waterworks the speed of a current decreases to $0.72 \mathrm{~m} / \mathrm{s}$, in radius of $200 \mathrm{~m}-$ to $0.37 \mathrm{~m} / \mathrm{s}$, and in radius of $300 \mathrm{~m}-$ to $0.02 \mathrm{~m} / \mathrm{s}$. In summer drought season, during the water dump there was observed a more moderate current speed: $0.47 \mathrm{~m} / \mathrm{s}$ on the water bringing channel; $0.25 \mathrm{~m} / \mathrm{s}$ on removal from waterworks in radius of $50 \mathrm{~m}$; $0.15 \mathrm{~m} / \mathrm{s}$ in radius of $100 \mathrm{~m} ; 0.08 \mathrm{~m} / \mathrm{s}$ in radius of $150 \mathrm{~m}$. 
Hydrobiological indicators. The taxonomic structure of zooplankton organisms in the Kirov Reservoir is presented by 18 taxa of invertebrates. Eight representatives of zooplanktonofauna were found in 2021, from them the Cladozer - 6, copepod - 2, rotifers were not found. The absence of rotifers can be explained by the unfavorable weather conditions at the time of sampling; they will probably restore their population next year. In 2021 the list of cladoceras was replenished with new species: A. harpae and A. emarginatus. Among copepods a new representative of crustaceans, Eurytemora minor, was registered; they were also dominants. Small cladoceras B. longirostris acted as subdominants. As a result of a quantitative analysis of the zooplankton of the Kirov Reservoir, it was found that copepods $(92.0 \%)$ prevailed in abundance, while copepods also dominated in terms of biomass $(94.7 \%)$. Cladoceras in the surveyed biotope were represented by single specimens in 2021, which affected the final biomass values. This is probably due to the fact that of all the groups of zooplankton cladoceras are the favorite food for fish juveniles. The total number of zooplankton in the Kirov Reservoir in 2021 was 1.88 thousand ind. $/ \mathrm{m}^{3}$. The biomass value of $118.71 \mathrm{mg} / \mathrm{m}^{3}$ indicates low productivity of zooplankton.

Zoobenthos of the Kirov Reservoir is presented by oligeclates, leeches, larvae of water insects (mosquito-bells, hoarse, muddens, swirls), bivalve and brickeloous mollusks [10]. The distribution of zoobenthos of the Kirov Reservoir for quantitative indicators, which in communities were dominated by unauthorized worms, the biomass - mollusks-unionida and leeches that are not feed organisms. The total number of zoobenthos of the Kirov Reservoir amounted to $3230 \mathrm{ex} . / \mathrm{m}^{2}$ in 2021 . The value of biomass $5.5 \mathrm{~g} / \mathrm{m}^{2}$ indicates the average productivity of zoobenthos in the studied period.

Icthyological indicators. The basic ichthyofauna of the Kirov Reservoir is presented by the species living in the Ural River. In the historically developed natural system of outflow the Kushum River is characterized by the annual migrations of fish going on spawning. After registering the rivers and formations of the Kushum Channel with the cascade of the reservoirs, the natural spawning ways have not been blocked. At the same time, the conditions were created for some of the increasing populations to remain here for a long time for acclimatization. In this connection, by the developed tradition these species are included into the specific lists as native. The scientific catches of 2021 included such species as pike, bream, silver carp, roach and perch.

Pike in the research catches made $4.2 \%$ from the total of the caught fishes. Their basic biological indicators are presented in Table 1.

Table 1

The basic biological indicators of pike in the Kirov Reservoir, 2021

\begin{tabular}{|c|c|c|c|c|c|c|}
\hline Age range & Length, sm (min-max) & Average length, sm & Weight, g (min-max) & Average weight, g & $n *$ & $\% * *$ \\
\hline $2+$ & $31.1-32.0$ & 31.6 & $283-321$ & 296 & 3 & 33.4 \\
\hline $3+$ & $35.5-36.0$ & 35.8 & $415-424$ & 420 & 2 & 22.2 \\
\hline $4+$ & $39.4-43.0$ & 41.2 & $521-793$ & 657 & 2 & 22.2 \\
\hline $7+$ & $62.5-63.0$ & 62.8 & $2569-2595$ & 2582 & 2 & 22.2 \\
\hline
\end{tabular}

* Number of fish in age groups; ** catchpercentage of age groups.

Analysis of Table 1 shows that the population is represented by fish aged from 2 to 7 years. The difference in the number of fish by age groups is small, which indicates a good survival of the species. The ratio of females and males is $5: 4$, respectively. The fatness of the caught fish averaged 0.95 according to Fulton, and 0.87 according to Clarke.

The share of bream in research catches in 2021 was $93.0 \%$ of the total fish caught. Thus, bream was the most frequently caught species. The studied part of the population was represented by individuals of 5-10 years old. Their main biological parameters are presented in Table 2.

Table 2

The basic biological indicators of bream in the Kirov Reservoir, 2021

\begin{tabular}{|c|c|c|c|c|c|c|}
\hline Age range & Length, sm (min-max) & Average length, sm & Weight, g (min-max) & Average weight, g & $n^{*}$ & $\% * *$ \\
\hline $5+$ & $19.0-19.5$ & 19.3 & $149-159$ & 153 & 4 & 2.0 \\
\hline $6+$ & $20.0-23.2$ & 21.8 & $153-274$ & 220 & 45 & 22.7 \\
\hline $7+$ & $23.3-26.4$ & 24.4 & $257-405$ & 312 & 65 & 32.8 \\
\hline $8+$ & $27.0-29.8$ & 29.1 & $408-675$ & 567 & 53 & 26.8 \\
\hline $9+$ & $30.0-32.5$ & 30.1 & $561-781$ & 674 & 26 & 13.1 \\
\hline $10+$ & $33.0-34.0$ & 33.5 & $728-936$ & 833 & 5 & 2.6 \\
\hline
\end{tabular}

* Number of fish in age groups; ** catchpercentage of age groups. 
The ratio of females to males in the studied part of the population was $17: 13$. The fatness of the caught fish averaged 2.21 according to Fulton, and 1.97 according to Clarke.

Analysis of Table 2 shows that population is presented by fishes at the age from 5-10. The fishes of the senior age groups, on the result of equation of trade loading on a trade stock bream, are well presented.

The share of silver crucian in research catches of the Kirov Reservoir has made $0.5 \%$ from the total of the caught fish, had on one seven-year female. Its basic biological indicators are presented in Table 3. The fatness of the caught fish by Fulton has made 4.53, on Clark - 3.33.

Table 3

The basic biological indicators of silver crucian of the Kirov Reservoir, 2021

\begin{tabular}{|c|c|c|c|c|c|c|}
\hline Age range & Length, sm (min-max) & Average length, sm & Weight, g (min-max) & Average weight, $\mathbf{g}$ & $\boldsymbol{n}^{* *}$ & $\mathbf{\%}^{* * * *}$ \\
\hline $7+$ & $-*$ & 25.3 & $-*$ & 734 & 1 & 100.0 \\
\hline
\end{tabular}

* Only one fish caught; ** number of fish in age groups; *** catchpercentage of age groups.

Table 3 analysis shows that the fish population is characterized by fishes of advanced ages. The small number of crucian in the catch has casual character as in the reservoir there is steady enough population of this species.

Roach in research catches in the Kirov Reservoir was represented by $0.9 \%$ of the total number of fish caught. The sample included 4- and 7-year-old females. Their basic biological indicators are presented in Table 4.

Table 4

The basic biological indicators of roach of the Kirov Reservoir, 2021

\begin{tabular}{|c|c|c|c|c|c|c|}
\hline Age range & Length, sm (min-max) & Average length, sm & Weight, g (min-max) & Average weight, $\mathrm{g}$ & $n^{* * *}$ & $\% * * *$ \\
\hline $4+$ & $-^{*}$ & 17.0 & ${ }^{*}$ & 117 & 1 & 50.0 \\
\hline $7+$ & $-^{*}$ & 24.3 & $-^{*}$ & 333 & 1 & 50.0 \\
\hline
\end{tabular}

* Only one fish caught; ** number of fish in age groups; *** catchpercentage of age groups.

Fatness of the caught fishes by Fulton on the average was 2.35, by Clark - 1.95.

Analysis of Table 4 shows that for population presence of fishes of advanced ages is characteristic. The small number of roach in the catch is rather random, since there is a fairly stable population of the species in the reservoir.

Perch in research catches in the Kirov Reservoir has been presented on $1.4 \%$ from the total of the caught fishes. Sampling included four - six-year individuals. Their basic biological indicators are presented in Table 5.

Table 5

The basic biological indicators of perch of the Kirov Reservoir, 2021

\begin{tabular}{|c|c|c|c|c|c|c|}
\hline Age range & Length, sm (min-max) & Average length, sm & Weight, g (min-max) & Average weight, g. & $n * *$ & $\% * * *$ \\
\hline $4+$ & $-*$ & 19.5 & $-*$ & 167 & 1 & 33.3 \\
\hline $6+$ & $22.5-22.7$ & 22.6 & $247-275$ & 261 & 2 & 66.7 \\
\hline
\end{tabular}

* Only one fish caught; $* *$ number of fish in age groups; *** catchpercentage of age groups.

The parity of females and males in the investigated part of population was $2: 1$ respectively. The fatness of the caught fishes by Fulton on the average has made 2.26, by Clark -2.01 .

Analysis of Table 5 shows that for population the presence of fishes of advanced ages is characteristic. A small number of perch in the catch has casual character, as it is a widespread species in the reservoir.

The research of the number of fish by the method of echo sounding showed a concentration of only 285 specimens per 1 ha.

An indicator of fishing fish product capacity was $32 \mathrm{~kg} / \mathrm{ha}$.

The data obtained on the study of the concentration and species composition of fish juveniles are shown in Table 6. 
Species composition and concentration of juveniles in the Kirov Reservoir, 2021

\begin{tabular}{|c|c|c|c|c|}
\hline Kind of juveniles & Development stage & Average length, mm & Average weight, g & Concentration, Ex. / ha \\
\hline Pike & juvenile & 52 & 2.49 & 348 \\
\hline Carp & juvenile & 48 & 1.34 & \\
\hline Bream & juvenile & 31 & 0.72 & \\
\hline Carp & juvenile & 27 & 0.57 & 2716 \\
\hline Roach & juvenile & 31 & 0.58 & \\
\hline Perch & juvenile & 32 & 0.71 & 1745 \\
\hline
\end{tabular}

Analysis of Table 6 shows that deviations from the average values of the sizes and weight for juveniles in the first stages is not observed. The most noticeable concentration of bream juveniles is due to the high size of the population. An interesting fact is that carp juveniles are observed in the reservoir, but adult fish are not found. The reservoir is annually stocked with carp yearlings, so they are found in juvenile samples. But obviously most of the juveniles leave their reservoirs during regular releases of water through the hydroelectric complex. This explains the absence of adult carp species in the reservoir.

\section{Conclusions}

The Kirov Reservoir has an even profile of the bottom and a rather small depth - to $3.2 \mathrm{~m}$ in the drought summer season to $4.2 \mathrm{~m}$ in the spring high water. In the spring when the water maximum quantity is dumped through the waterworks, the speed of a current on the water bringing channel increases to $1.94 \mathrm{~m} / \mathrm{s}$. On removal in radius of $100 \mathrm{~m}$ from waterworks the speed of a current decreases to $0.72 \mathrm{~m} / \mathrm{s}$, in radius of $200 \mathrm{~m}$ - to $0.37 \mathrm{~m} / \mathrm{s}$, and in radius of $300 \mathrm{~m}-$ to $0.02 \mathrm{~m} / \mathrm{s}$. In the drought summer season the speed of a current is more moderate and practically does not decrease on the removal from waterworks in radius more than $150 \mathrm{~m}$.

The forage reserve of fishes has low indicators on zooplankton, and averages on zoobenthos. However, considering that it is a residual biomass of fodder organisms, it is possible to speak about sufficient fish provision by natural feed resources.

The commercial fish fauna is represented by pike, bream, crucian carp, roach and perch, with a total commercial fish productivity of $32 \mathrm{~kg} / \mathrm{ha}$.

The trade ichthyofauna is presented by pike, bream, crucian carp, roach and perch, with a total trade fish productivity $32 \mathrm{~kg} / \mathrm{ha}$. Concentration of juveniles only $16399 \mathrm{sp}$./ha. Although the reservoir is annually stocked with carp underyearlings, which are found in the juvenile samples, no adult fish was found in the catches. A small quantity of the commercial species, their low productivity, and the absence of adult carp, despite the annual stocking of fish, speaks of the withdrawal of fish and juveniles from the reservoir during regular releases of water through the waterworks.

For preserving and increasing the trade ichthyofauna it is necessary to develop and install the effective the fish protecting devices. At the same time, its effect should cover the entire water area of the pre-dam part, at a distance of more than $300 \mathrm{~m}$ from the spillway of the hydroelectric complex, in order to protect adult fish and juveniles from drift by the current.

\section{REFERENCES}

1. Chibilev A. A. The Urals basin: history, geography, ecology. Yekaterinburg, Ural Branch of the Russian Academy of Sciences, 2008. 312 p.

2. On amendments to the Resolution of the WKO akimat of December 22, 2014 No. 325 "On approval of the list of fishery reservoirs and (or) local areas". Resolution of the WKO akimat of June 16, 2017 No. 176. Available at: https://adilet.zan.kz/rus/docs/V17Z0004868/historyjuvenile stage (accessed: 04.04.2021).

3. Bykov V. D., Vasiliev A. V. Hydrometry. Saint-Petersburg, Gidrometeoizdat Publ., 1977. Pp. 75-115.

4. Guidelines for the collection and processing of materials for hydrobiological research in freshwater reservoirs. Zoobenthos and its products. Leningrad, GosNIOH, ZIN AN SSSR, 1983. 52 p.

5. Keys to freshwater invertebrates of the European part of the USSR. Leningrad, Gidrometeoizdat, 1977. 512 p.

6. Maitland P. S., Linsell K. Philip's guide to freshwater fish of Britain and Europe. London, Philip's, 2006. Pp. 12-20.

7. Koblitskaya A. F. Keys to juvenile freshwater fish. Moscow, Legkaia i pishchevaia promyshlennost' Publ., 1981. 208 p.

8. Pravdin I. F. Guide to the study of fish. Moscow, Pishchevaia promyshlennost' Publ., 1966. 372 p.

9. Kim A. I. A method for assessing the number of fish with an echo sounder. Utility model patent No. 3242. Bulletin No. 40, Republican State Enterprise "National Institute of Intellectual Property"; Astana, 2018. 
10 Pilin D. V., Oskina A. A. Fauna of zoobenthos communities of the Ural-Kushum irrigation and watering system (North-Western Kazakhstan). Entomological and parasitological studies in the Volga region, 2017, no. 14 , pp. $30-34$.

The article submitted to the editors 21.06.2021

\title{
INFORMATION ABOUT THE AUTHORS
}

\begin{abstract}
Artur Tumenov - PhD, Branch Manager; Fisheries Research and Production Center, LLP; Republic of Kazakhstan, 050016, Almaty; Tumenov@fishrpc.kz.
\end{abstract}

Saule Zh. Assylbekova - Doctor of Biological Sciences, Assistant Professor; Deputy General Director; Fisheries Research and Production Center, LLP; Republic of Kazakhstan, 050016, Almaty; assylbekova@mail.ru.

Arkadiy Kim - Head of Fisheries Laboratory; Fisheries Research and Production Center, LLP; Republic of Kazakhstan, 050016, Almaty; Kim@fishrpc.kz.

Alyona A. Mukhramova - Chief Academic Secretary; Fisheries Research and Production Center, LLP; Republic of Kazakhstan, 050010, Almaty; mukhramova@fishrpc.kz.

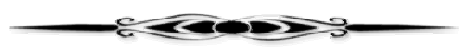

\section{ИССЛЕДОВАНИЕ КИРОВСКОГО ВОДОХРАНИЛИЩА ДЛЯ РАЗРАБОТКИ АКТИВНОГО ПЕРЕДВИЖНОГО ГИДРОАКУСТИЧЕСКОГО РЫБОЗАЩИТНОГО УСТРОЙСТВА}

\author{
А. Н. Туменов, С. Ж. Асылбекова, А. И. Ким, А. А. Мухрамова \\ ТОО «Научно-производственный центр рыбного хозяйства, \\ Алматы, Республика Казахстан
}

\begin{abstract}
Описаны гидрологические, гидробиологические и ихтиологические параметры Кировского водохранилища, расположенного в Западно-Казахстанской области Республики Казахстан. Водоем выбран в качестве модельного для выполнения грантового проекта № AР09058066 «Разработка активного передвижного гидроакустического рыбозащитного устройства для защиты рыб и молоди от попадания в водосбросы плотин крупных ГЭС и водохранилищ» Министерства образования и науки Республики Казахстан. Гидрологические, гидробиологические и ихтиологические исследования проводились с целью получения данных для принятия оптимальных решений по разработке конструкции, комплектации и рабочего алгоритма рыбозащитного устройства. Гидрологические исследования включают в себя промеры глубин и скоростей течения на акватории водохранилища и перед водосбросом плотины. В качестве гидробиологических показателей исследовались видовой состав, численность и биомасса кормовых беспозвоночных зоопланктона и зообентоса. При изучении ихтиологических данных принимались во внимание видовой состав, основные биологические показатели, численность и биомасса рыб, а также видовой состав и концентрация молоди. Полученные гидрологические, гидробиологические и ихтиологические параметры Кировского водохранилища явились основой для разработки концепции активного передвижного гидроакустического рыбозащитного устройства для защиты рыб и молоди от попадания в водосбросы плотин крупных ГЭС и водохранилищ.
\end{abstract}

Ключевые слова: водохранилище, плотина, глубина, течение, зоопланктон, зообентос, биомасса, рыбы, концентрация.

Для цитирования: Туменов А. Н., Асылбекова С. Ж., Ким А. И., Мухрамова А. А. Исследование Кировского водохранилища для разработки активного передвижного гидроакустического рыбозащитного устройства // Вестник Астраханского государственного технического университета. Серия: Рыбное хозяйство. 2021. № 3. С. 102-108. DOI: 10.24143/2073-55292021-3-102-108. 


\title{
СПИСОК ЛИТЕРАТУРЫ
}

1. Chibilev A. A. The Urals basin: history, geography, ecology. Yekaterinburg: Ural Branch of the Russian Academy of Sciences, 2008. 312 p.

2. On amendments to the Resolution of the WKO akimat of December 22, 2014 No. 325 "On approval of the list of fishery reservoirs and (or) local areas.”: Resolution of the WKO akimat of June 16, 2017 No. 176. URL: https:/adilet.zan.kz/rus/docs/V17Z0004868/historyjuvenile stage (дата обращения: 04.04.2021).

3. Bykov V. D., Vasiliev A. V. Hydrometry. Spb.: Gidrometeoizdat, 1977. P. 75-115.

4. Guidelines for the collection and processing of materials for hydrobiological research in freshwater reservoirs // Zoobenthos and its products. L.: GosNIOH, ZIN AN SSSR, 1983. 52 p.

5. Keys to freshwater invertebrates of the European part of the USSR / Otv. ed. L. A. Kutikova, Ya. I. Starobogatov. L.: Gidrometeoizdat, 1977. 512 p.

6. Maitland P. S., Linsell K. Philip's guide to freshwater fish of Britain and Europe. London: Philip's, 2006. P. $12-20$.

7. Koblitskaya A. F. Keys to juvenile freshwater fish. М.: Лег. и пищ. пром-сть, 1981. 208 p.

8. Pravdin I. F. Guide to the study of fish. М.: Пищ. пром-сть, 1966. 372 p.

9. Utility model patent No. 3242 A method for assessing the number of fish with an echo sounder / Kim A. I. Bulletin No. 40, Republican State Enterprise "National Institute of Intellectual Property"; Astana, 2018.

10. Pilin D. V., Oskina A. A. Fauna of zoobenthos communities of the Ural-Kushum irrigation and watering system (North-Western Kazakhstan) // Entomological and parasitological studies in the Volga region. 2017. N. 14. P. 30-34.

Статья поступила в редакцию 21.06.2021

\section{ИНФОРМАЦИЯ ОБ АВТОРАХ}

\begin{abstract}
Артур Насибуллаевич Туменов - $\mathrm{PhD}$; директор филиала; ТОО «Научно-производственный центр рыбного хозяйства»; Республика Казахстан, 050016, Алматы; Tumenov@fishrpc.kz.
\end{abstract}

Сауле Жангировна Асылбекова - д-р биол. наук, доцент; зам. генерального директора; ТОО «Научно-производственный центр рыбного хозяйства»; Республика Казахстан, 050016, Алматы; assylbekova@mail.ru.

Аркадий Игнатьевич Ким - заведующий рыбохозяйственной лабораторией; ТОО «Научно-производственный центр рыбного хозяйства»; Республика Казахстан, 050016, Алматы; Kim@fishrpc.kz.

Алена Александровна Мухрамова - главный ученый секретарь; ТОО «Научно-производственный центр рыбного хозяйства»; Республика Казахстан, 050016, Алматы; mukhramova@fishrpc.kz. 